\title{
TWO NEW PAUSSID BEETLES FROM THE PANAMA CANAL ZONE AND THE PHILIPPINES ${ }^{1}$
}

\author{
By P. J. Darlington, JR. \\ Museum of Comparative Zoölogy, Cambridge, Mass.
}

The following two new species of paussid beetles are described here for reference in other connections.

Homopterus (s. s.) subcordatus n. sp.

Fig. 1

Form average in genus; castaneous, moderately shining; most of head, pronotum, and elytra rather closely punctate with punctures of moderate size, but not obviously pubescent (some of the punctures have very short hairs which scarcely rise above the level of the body surface). Head across eyes (not including post-ocular tubercles) about $5 / 6$ as wide as prothorax; post-ocular tubercles prominent; occiput only vaguely swollen; front concave, with a pair of deeper impressions within the concavity; antennae as figured, the flattened segments irregularly granulate above, more closely so on the anterior sides of the transverse segments and around the apical segment, the granules bearing short, inconspicuous hairs; mouth-parts normal for genus. Prothorax as figured, wide, with sides sinuate before base; disk convex, slightly swollen on each side, rather deeply longitudinally impressed at middle; disk also vaguely impressed or flattened across base and apex; lateral margins unusually broad, running into moderate baso-lateral impressions. Elytra rather elongate (in genus), about $1 / 4$ wider than prothorax, subparallel, with outer sides very weakly arcuate. Femora and tibiae only moderately wide in genus. Pygidium closely punctate; preceding dorsal abdominal segment more finely and less closely so. Male copulatory organs as figured. Length to apex of elytra, about $8 \mathrm{~mm}$.; width, about $3 \mathrm{~mm}$. or slightly more (both specimens too warped for accurate measurement of width).

Holotype $\hat{o}$ in the Museum of Comparative Zoölogy (No. 28,369) from Barro Colorado Island, Panama Canal Zone, 5-6-37, col-

${ }^{1}$ Published with a grant from the Museum of Comparative Zoölogy at Harvard College. 
lected and very kindly presented by Prof. S. W. Frost. One $\hat{o}$ paratype in the United States National Museum (No. 59,425) from the same locality, June 1940, collected by James Zetek (original No. Z-4669).
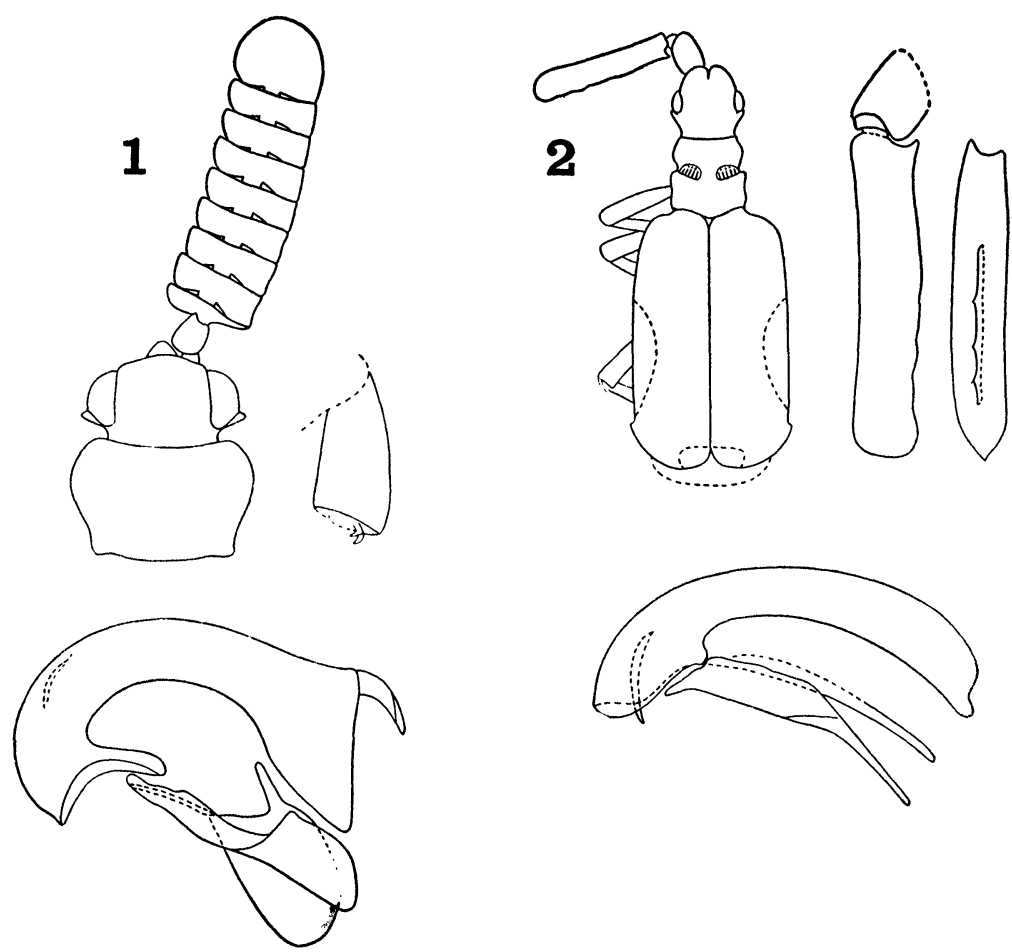

Fig. 1. Homopterus subcordatus n. sp. (Holotype $\hat{\text { ) }}$ ): prothorax, head, and right antenna; left hind tibia with retractile tarsus indicated; and male copulatory organs from left.

Fig. 2. Paussus occlusus n. sp. (Holotype 1 ) : whole insect; left antenna from above and (flagellum only) from behind; and male copulatory organs from left.

The subcordate prothorax, prominent post-ocular tubercles, unusually wide lateral prothoracic margins, triangular rather than rounded tibiae, absence of distinct pubescence on upper surface of body, and antennal form are characters which, combined, distinguish 
this new species from all previously known Homopterus. The antennae are intermediate in form within the genus, with the posterior edges of the flagellar segments not so straight as in kriegi Reichensp., bolivianus Kolbe, or brasiliensis Westw., but not so deeply emarginate as in steinbachi Kolbe etc, (cf. Reichensperger 1938, Figs. 1-8). As compared with $H$. hondurensis Darl., which is of about the same size and general appearance and which also occurs on Barro Colorado Island (five specimens from various sources in M. C. Z. and U. S. N. M.), the present new species has a more cordate prothorax, slightly different antennae, and more prominent post-ocular tubercles, and the new species lacks the light but distinct pubescence of hondurensis.

I suspect, incidentally, that my Homopterus hondurensis (1937) and $H$. kriegi Reichensperger (1938) are the same, but a comparison of specimens will be necessary to establish the synonymy.

\section{Paussus occlusus n. sp.}

Fig. 2

Form as figured, convex; color light brown, redder anteriorly, with the following parts black or piceous: anterior and supra-ocular callosities of head, lateral and apical marks of elytra, lower surfaces of head and prothorax and (in part) mesothorax, and main portions of appendages; surface of body above (including elytra) and below dull, microscopically wrinkled; pubescence above of rather sparse, short, slightly curved, slightly thickened, yellowish hairs (this type of pubescence lacking in depressions of back of head and of pronotum, and rubbed off inner portions of disk of elytra); pubescence below of more inconspicuous, minute, pale hairs. Head: front with 2 longitudinal, parallel ridges anteriorly, curving in and nearly meeting above bases of antennae, and with 4 tubercles, 1 median, 1 occipital, and 1 above and behind each eye, each supraocular tubercle with a semicircular impression concave inwardly; antennae as figured, flagellum sub-cylindrical, with fine raised margin along anterior edge, and with the vestige of a longitudinal sulcus posteriorly under a slight ridge which shows traces of segmentation although the bottom of the sulcus does not; surface of both basal and flagellar parts of antennae closely, coarsely punctate, each puncture with a short, slightly thickened, pale hair; labial and especially maxillary palpi broad, moderately flattened, more finely sculptured and pubescent than antennae. Prothorax deeply, trans- 
versely divided, with large trichomes in the cleft on each side, and pronotum also with a less sharply defined longitudinal depression, widest basally but deepest toward the middle. Elytra and pygidium without dense trichome-fringes or special marginal hairs; pygidial margin indistinct. Legs not flattened. Male copulatory organs as figured. Length (to apex of elytra), just over $7 \mathrm{~mm}$.

Holotype $\hat{o}$ in the United States National Museum (No. 59,426) from Biliran Island [north of Leyte], Philippine Islands, C. F. Baker Collection; unique.

This new Paussus goes in a group to which belong also $P$. catoxanthus Gestro, tagalicus Gestro, and kolbei Reichensperger. The group in the strictest sense may be confined to the Philippines, but it is probably related to Paussus waterhousei Westwood and some other Oriental-Malayan forms. The new species is probably closest to tagalicus (Gestro 1918), which it resembles in coloration and most other details, but the new species is distinguished from tagalicus by much more strongly tuberculate head and much narrower posterior sulcus of the antennal flagellum.

\section{REFERENCES}

Darlington, P. J., JR.

1937. A new paussid bettle from Central America. Psyche 44, 56-7. Gestro, R.

1918. Sui Paussidi delle Isole Filippine. Ann. Mus. Civ. Genova 48, 5-8. REICHENSPERGER, A.

1938. Sudamerikanische Paussiden (Col.) und einige Vorbemerkungen. Rev. de Entomologia (Rio de Janeiro) 8, 68-79. 

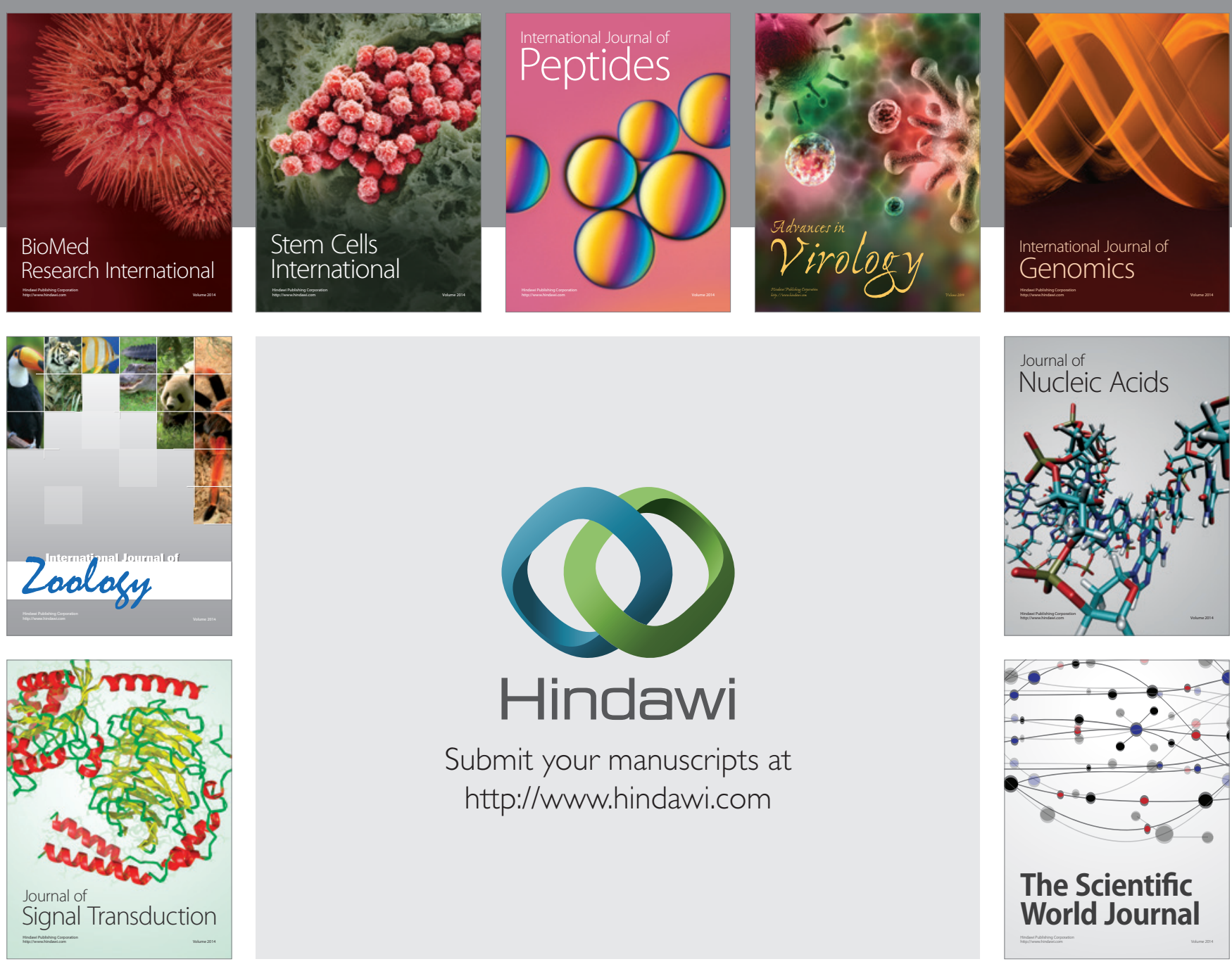

Submit your manuscripts at

http://www.hindawi.com
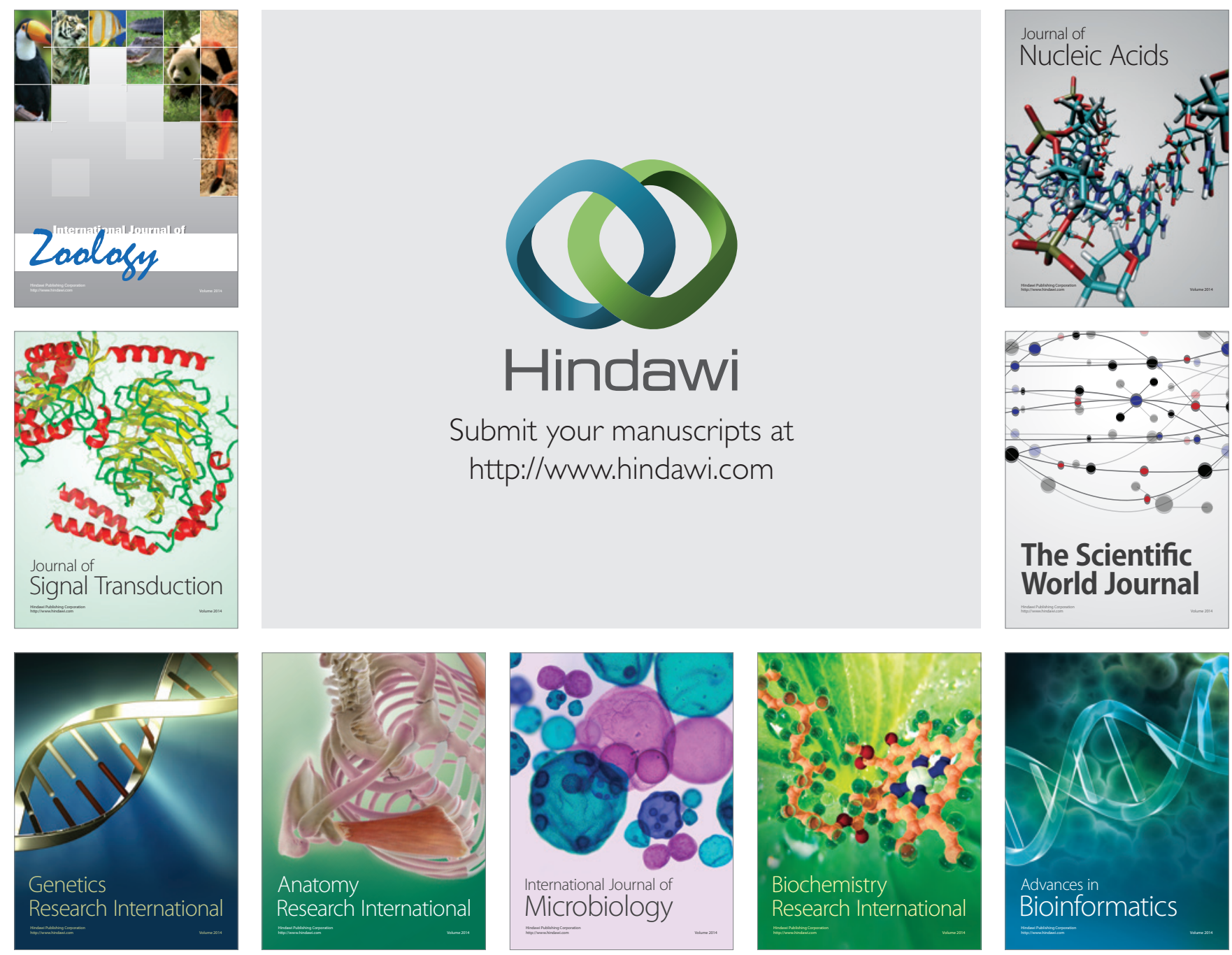

The Scientific World Journal
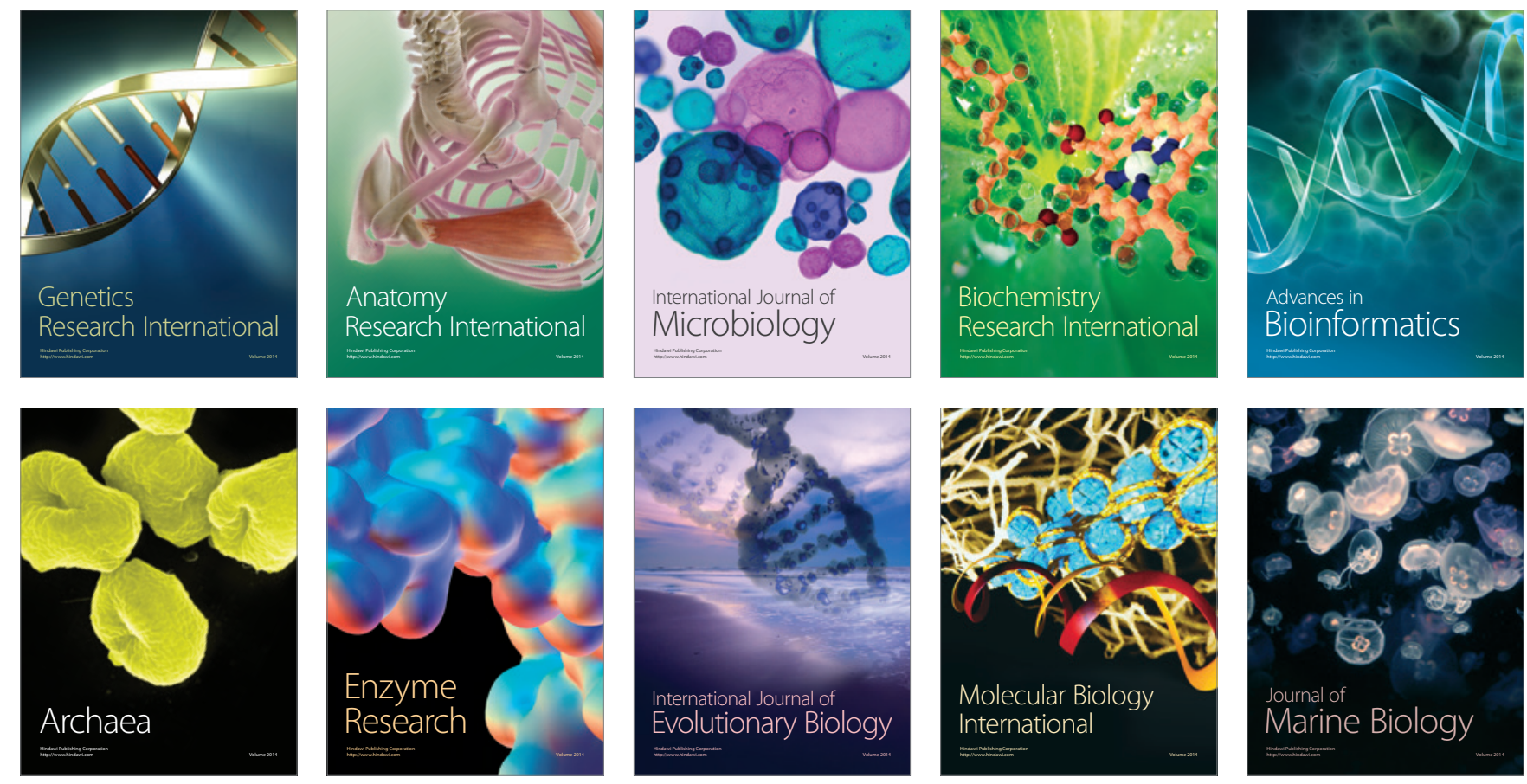